Abstracta Iranica Iranica

Revue bibliographique pour le domaine irano-aryen

Volume 30 | 2010

Comptes rendus des publications de 2007

\title{
Șafhe sangī / Persian Discography Journal (9-12), Téhéran, 2007.
}

Ariane Zevaco

\section{Q OpenEdition \\ 12 Journals}

Édition électronique

URL : http://journals.openedition.org/abstractairanica/38223

DOI : 10.4000/abstractairanica.38223

ISSN : 1961-960X

\section{Éditeur :}

CNRS (UMR 7528 Mondes iraniens et indiens), Éditions de l'IFRI

\section{Édition imprimée}

Date de publication : 8 avril 2010

ISSN : 0240-8910

\section{Référence électronique}

Ariane Zevaco, « Șafhe sangī / Persian Discography Journal (9-12), Téhéran, 2007. », Abstracta Iranica [En ligne], Volume 30 | 2010, document 365, mis en ligne le 08 avril 2010, consulté le 01 octobre 2020. URL : http://journals.openedition.org/abstractairanica/38223; DOI : https://doi.org/10.4000/ abstractairanica.38223

Ce document a été généré automatiquement le 1 octobre 2020.

Tous droits réservés 


\title{
Șafhe sangī / Persian Discography Journal (9-12), Téhéran, 2007.
}

\author{
Ariane Zevaco
}

Ce troisième volume de Șafhe sangī, revue dédiée à l'histoire et à l'étude des enregistrements de la musique iranienne, éditée (ainsi qu'écrite, en grande partie) par Amīr Manșūr, amateur très éclairé de musique (entre autres iranienne) et inlassable collectionneur d'enregistrements, rassemble les quatre numéros parus en 2007/1386. Les sujets abordés sont divers, allant de la discographie de Ḥoseyn 'Alī Huān Nakīsā (vol. 9), à l'histoire de la musique pop iranienne (vol. 12), en passant par l'analyse des différentes versions enregistrées de «Mara Bebus» de Majīd Vafādār (vol. 9). Différentes rubriques sont présentées dans chaque numéro: un document inédit (partition, enregistrement), un article de « labellographie », un de " discographie », une analyse d'enregistrement et souvent la recension de catalogues des compagnies d'enregistrements (Polyphone, Gramophone, etc.). Surtout, les différents articles démontrent une recherche rigoureuse, toujours référencée et agréablement illustrée, qui ne peut que servir aux chercheurs en histoire et évolution des musiques iraniennes (savante, régionales ou " pop »), sur lesquelles les processus d'enregistrements ont eu et ont encore - un impact tout à fait évident.

\section{INDEX}

Thèmes : 17.1.Musique 


\section{AUTEURS}

ARIANE ZEVACO

Paris 